\title{
Pemenuhan Sarana dan Prasarana bagi Masyarakat Berkebutuhan Khusus untuk Meningkatkan Kualitas Pelayanan Publik di Daerah
}

\author{
Ricky Noor Permadi \\ Puslatbang KDOD-Lembaga Administrasi Negara \\ rickypermadi93@gmail.com \\ Wildan Lutfie Arieyasmieta \\ Puslatbang KDOD-Lembaga Administrasi Negara \\ wildan.arieyasmieta@gmail.com \\ Rustan Amarullah \\ Puslatbang KDOD-Lembaga Administrasi Negara \\ rustanamarullah8@gmail.com
}

\begin{abstract}
This study aims to analyze to what extent the provision of the rights of special needs groups has been implemented and provide recommendations related to the additional infrastructure outside the regulation of the Ministry of State Apparatus Utilization and Bureaucratic Reform (PANRB) Number 17 of 2017. This study is vital since the government institutions still lack attention to fulfilling the rights of persons with disabilities. In accordance with the mandate of Law Number. 25 of 2009 concerning Public Services, public service providers are obliged to provide special facilities and infrastructure for special needs groups without any additional charge. The research method used in this research is descriptive qualitative by analyzing the existing literature (library research). Then data collection through field observations (observations), interviews, and other library sources. This study tries to look at the completeness of special facilities and infrastructure for people with special needs that are provided by recommending twenty-two standards for infrastructure intended for "people with special needs". Some public service providers relatively have almost met the standards. However, there are also public service providers which still need to be encouraged to meet these standards. It is necessary to have the political will of regional leaders to prioritize the provision of facilities and infrastructure to support public services for people with special needs. Amid limited regional resources, prioritizing the stages of fulfilment (road map) of these special facilities needs to be prepared, and partnerships also collaborations with other strategic partners can be developed to help meet these special service standards. There are limitations in this research: only three public service providers are the locus of the study, including hospitals, the Department of Population and Civil Registration, and the Department of Investment and the One-Stop Service, so that it does not represent the condition of public services in a city.
\end{abstract}

Keywords: public services, accessibility, special needs, facilities, infrastructure

Corresponding author(s): Rustan Amarullah, Email: rustanamarullah8@gmail.com

Article history: Received,29 September 2021; Revised, 13 November 2021; Accepted, 17 November 2021.

To cite this article: Permadi, R. N., Arieyasmieta, W. L., \& Amarullah, R. (2021). Pemenuhan Sarana dan Prasarana bagi Masyarakat Berkebutuhan Khusus untuk Meningkatkan Kualitas Pelayanan Publik di Daerah. JPSI (Journal of Public Sector Innovations), 06(1), 28-38. https://doi.org/10.26740/jpsi.v6n1.p28-38 


\title{
Provision of Facilities for People with Special Needs to Improve the Quality of Public Services in the Regions
}

\begin{abstract}
Abstrak
Tujuan penelitian ini adalah untuk menganalisis sejauh mana pemenuhan hak-hak kelompok berkebutuhan khusus telah diimplementasikan dan memberikan rekomendasi terkait dengan sarana-prasarana tambahan di luar peraturan Kementerian PANRB Nomor 17 Tahun 2017. Penelitian ini penting untuk dilakukan karena masih kurangnya perhatian lembaga pemerintah dalam hal pemenuhan hak-hak penyandang disabilitas. Sesuai pasal 29 UU No. 25 Tahun 2009 bahwa penyelenggara pelayanan publik berkewajiban menyediakan sarana dan prasarana khusus bagi masyarakat berkebutuhan khusus tanpa pembebanan biaya tambahan. Metode penelitian yang digunakan dalam penelitian ini adalah kualitatif deskriptif. Pengumpulan data dilakukan melalui pengamatan lapangan, wawancara, dan sumber pustaka. Hasil penelitian menggambarkan kondisi sarana dan prasarana khusus bagi masyarakat berkebutuhan khusus yang disediakan dengan merekomendasikan dua puluh dua standar sarana prasarana bagi masyarakat berkebutuhan khusus. Beberapa penyedia pelayanan publik relatif sudah memenuh sarana prasarana tersebut. Namun, juga terdapat penyedia layanan publik yang perlu didorong untuk memenuhi standar pelayanan khusus tersebut. Untuk memenuhi standar pelayanan bagi kelompok rentan, diperlukan political will pemimpin daerah untuk turut memprioritaskan penyediaan sarana dan prasarana penunjang pelayanan publik bagi masyarakat berkebutuhan khusus. Di tengah keterbatasan sumberdaya daerah, maka pengutamaan tahapan pemenuhan (road map) fasilitas khusus tersebut perlu disiapkan, serta pola-pola kemitraan dan kolaborasi dengan mitra strategis lainnya dapat dikembangkan untuk membantu memenuhi standar pelayanan khusus tersebut. Keterbatasan penelitian ini yaitu hanya mencakup tiga penyelenggara pelayanan publik, yang meliputi RSUD, Dinas Kependudukan dan Pencatatan Sipil dan Dinas Penanaman Modal dan Pelayanan Terpadu Satu Pintu sehingga tidak menggambarkan kondisi pelayanan publik suatu daerah.
\end{abstract}

Kata Kunci: pelayanan publik, aksesibilitas, berkebutuhan khusus, fasilitas, infrastruktur

\section{PENDAHULUAN}

Pelayanan publik di Indonesia perlu memberikan perhatian kepada masyarakat berkebutuhan khusus, dimana negara juga wajib hadir untuk memberikan pelayanan yang terbaik. Pelayanan kepada masyarakat berkebutuhan khusus sebagaimana dimaksud dalam UU No. 25 Tahun 2019 tentang Pelayanan Publik adalah pelayanan kepada kaum difabel, lansia, anakanak, serta wanita hamil dan ibu menyusui. Sebagaimana diketahui bahwa Kementerian PANRB selaku pembina pelayanan publik telah berupaya untuk mendorong setiap instansi agar dapat menyediakan berbagai sarana dan prasarana bagi kaum rentan, salah satunya melalui pelaksanaan evaluasi pelayanan publik yang dilakukan setiap tahun.

Berdasarkan hasil pemantauan dan evaluasi yang dilakukan dalam tiga tahun terakhir perkembangannya cukup menggembirakan (Gambar 1), meskipun demikian upaya yang dilakukan oleh unit pelayanan untuk menyediakan sarana prasarana masih belum optimal, khususnya pada unit pelayanan yang diselenggarakan oleh pemerintah daerah. Kondisi ini yang kemudian mengindikasikan bahwa pemerintah daerah masih perlu melakukan peningkatan ketersediaan sarana bagi masyarakat berkebutuhan khusus yang dikhususkan pada sektor unit pelayanan pemerintah (Kementerian PANRB, 2020). Sejalan dengan semangat pelayanan publik dimana perlunya dilakukan percepatan untuk dapat memenuhi sarana dan prasarana yang menunjang pemenuhan kebutuhan bagi masyarakat berkebutuhan khusus.

Gambar 1. Perkembangan Indeks Pelayanan Publik Nasional

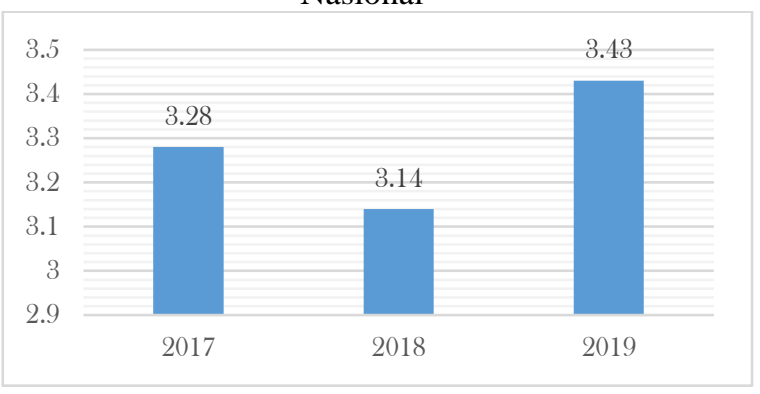

Sumber: LAKIP Deputi Bidang Pelayanan PublikKemenpanRB, 2019 
Dalam pengukuran Indeks Pelayanan Publik (IPP) sesuai permenpan No. 17 Tahun 2017 tentang pedoman penilaian kinerja unit penyelenggara pelayanan publik, didasarkan pada enam aspek, yakni kebijakan pelayanan, profesionalisme SDM, sarana dan prasarana, sistem informasi pelayanan publik (SIPP), konsultasi dan pengaduan, serta inovasi pelayanan. Khusus pada penilaian sarana dan prasarana, salah satu aspek yang dinilai adalah sarana dan prasarana masyarakat berkebutuhan khusus. Oleh karena itu, untuk dapat memberikan pelayanan yang prima kepada masyarakat berkebutuhan khusus, Setiap Kementerian/Lembaga/Daerah diharapkan menyediakan fasilitas sarana prasarana bagi masyarakat berkebutuhan khusus yang terstandar dengan jumlah yang cukup.

Pada tahun 2018 Ombudsman Republik Indonesia melakukan penilaian kepatuhan terhadap 9 kementerian, 4 lembaga, 16 provinsi, dan 49 pemerintah kota dan 199 pemerintah kabupaten. Penilaian menggunakan variabel dan indikator berbasis pada kewajiban pejabat pelayanan publik dalam memenuhi komponen standar pelayanan publik sesuai dengan UU Pelayanan Publik. Total sebanyak 97 instansi pemerintah mendapatkan penilaian kepatuhan tinggi atau berada pada zona hijau, 120 instansi pemerintah mendapatkan penilaian kepatuhan sedang atau masuk dalam zona kuning, dan 60 instansi pemerintah berada pada zona merah atau dengan predikat penilaian rendah (Ombudsman Republik Indonesia, 2018).

Perihal pemenuhan sarana dan prasarana terhadap masyarakat berkebutuhan khusus, tidak sedikit instansi pemerintah yang telah berkomitmen untuk memberikan pelayanan publik terbaik. Terdapat instansi pemerintah yang telah melakukan perbaikan untuk pemenuhan sarana dan prasarana masyarakat berkebutuhan khusus, seperti Kementerian Keuangan RI, khususnya di KPKNL Ternate. Contoh lain juga di dapati di Kementerian Perhubungan dengan keberhasilannya mendapatkan penghargaan sebagai role model pelayanan publik yang ramah masyarakat berkebutuhan khusus. Terdapat tiga Unit Pelayanan Publik yang kemudian dijadikan percontohan yaitu, Terminal Tipe A Soekarno Klaten Jawa Tengah, Kantor Kesyahbandaran Utama Makassar, dan Balai Pengelola Kereta Api Ringan (LRT) Sumatera Selatan. Ini adalah contoh dari instansi pemerintah yang terus berusaha untuk memenuhi sarana dan prasarana pelayanan publik terhadap masyarakat berkebutuhan khusus (Kementerian Perhubungan, 2021).

Beberapa penelitian yang telah dilakukan terkait pemenuhan sarana dan prasarana pelayanan publik kepada masyarakat berkebutuhan khusus di tingkat pemerintah daerah relatif tidak cukup banyak. Salah satunya penelitian di Kabupaten Timor Tengah Selatan (Ndaumanu, 2020:131-150), dimana penulis mengungkapkan bahwa hak penyandang disabilitas masih belum terpenuhi secara maksimal karena minimnya program dan kegiatan bagi penyandang disabilitas. Dibutuhkan peraturan daerah yang menjabarkan kewajiban pemerintah daerah atas hak penyandang disabilitas. Pemahaman masyarakat, perangkat desa dan perangkat daerah terhadap upaya penghormatan, pelindungan dan pemenuhan hak penyandang disabilitas masih kurang dalam melihat hak-hak penyandang disabilitas yang harus dipenuhi sebagai tanggung jawab bersama.

Pada sektor publik yang lain juga dapat dilihat bahwa pemenuhan aksesibilitas dalam setiap fasilitas pelayanan publik pada sektor perbankan merupakan bentuk penghormatan dan dalam mendukung kemandirian difabel terhadap pelaksanaan proses pelayanan. Aksesibilitas yang dibutuhkan termasuk kemampuan berkomunikasi kepada difabel dalam melakukan pelayanan, seperti tersedianya huruf braille dan dapat menggunakan bahasa tubuh (Buana \& Rudy, 2018:1-14). Kondisi ini menunjukkan bahwa sektor layanan di perbankan telah memberikan perhatian lebih pada pelayanan bagi masyarakat berkebutuhan khusus.

Pada penelitian yang lain ditemukan bahwa tidak adanya kepastian data mengenai jumlah penyandang disabilitas di Indonesia justru menjadi kendala dalam penanganan layanan pada masyarakat berkebutuhan khusus. Penyandang disabilitas masih mengalami kesulitan dalam mengakses informasi, pendidikan, pekerjaan, transportasi serta layanan publik lainnya. Jika dilihat pada konsep CRPD (Convention on The Rights of Person with Disabilities) yang kemudian implementasikan pada Perda DKI Jakarta Nomor 10 tahun 2011 tentang perlindungan penyandang disabilitas, ternyata masih belum berjalan secara optimal (Propiona, 2021:1-18). Peningkatan aksesibilitas signifikan hanya terjadi pada fasilitas transportasi umum yaitu bus TransJakarta. Penelitian tersebut menyebutkan bahwa perlu adanya upaya yang berkelanjutan dari Pemda DKI Jakarta untuk memberikan kota yang nyaman dan ramah bagi disabilitas.

Kerap kali penyelenggara pelayanan publik melupakan fasilitas penunjang bagi kaum rentan. Hal tersebut terlihat dari penelitian yang dilakukan oleh Thohari (2014) yang menyatakan bahwa dari 125 bangunan publik yang ada di Kota Malang, didapati bahwa sebagian besar gedung tidak memenuhi aksesibilitas bagi penyandang disabilitas. Sekitar $85 \%$ dari fasilitas publik yang di survei tidak memiliki jalur landai (ram) untuk jalur kursi roda, jika pun ada ada, jalur landai tersebut tidak aksesibel (terlalu curam) bagi pengguna kursi roda. Selanjutnya sebanyak 83\% bangunan publik juga tidak dilengkapi dengan toilet khusus penyandang disabilitas. Selain itu, bangunan publik yang di survei juga tidak dilengkapi dengan parkiran khusus penyandang disabilitas.

Selanjutnya, penelitian Syafi'ie (2014) mengemukakan bahwa secara umum pemenuhan aksesibilitas bagi penyandang disabilitas pada kantorkantor pemerintahan dan swasta di Yogyakarta masih 
jauh dari kata layak untuk penyandang disabilitas, tidak semua fasilitas publik dan kantor-kantor pemerintahan aksesibel. Sama halnya seperti yang terjadi di Kabupaten Garut, pemberian pelayanan publik kepada masyarakat berkebutuhan khusus masih menjadi masalah yang belum teratasi, seperti kurangnya fasilitas khusus bagi kaum rentan, hingga terbatasnya tenaga profesional yang mendukung penyandang disabilitas dalam menerima layanan publik (Pasciana, 2020). Aksesibilitas seharusnya dapat disediakan oleh setiap penyelenggara pelayanan publik secara nyata demi melindungi setiap hak-hak bagi disabilitas sehingga memudahkan para masyarakat berkebutuhan khusus dalam mendapatkan pelayanan publik. Keterbatasan akses layanan publik yang diterima oleh masyarakat berkebutuhan khusus salah satunya terjadi karena belum adanya perhatian khusus dari penyelenggara pelayanan publik atas fasilitas penunjang bagi masyarakat berkebutuhan khusus (Palenewen, 2019).

Permasalahan fasilitas penunjang bagi masyarakat berkebutuhan khusus tidak hanya terjadi di Indonesia, beberapa negara berkembang lainnya juga menghadapi permasalahan yang sama. Banyak penelitian yang juga membuktikan bahwa pemenuhan fasilitas untuk penyandang disabilitas dan masyarakat berkebutuhan khusus masih kurang diperhatikan. Seperti yang terjadi di Sri Lanka, Keerthirathna, Karunasena, \& Rodrigo (2018) mengidentifikasi bahwa rata-rata toilet yang disediakan pada kantor-kantor pemerintah dan swasta tidak sesuai dengan kebutuhan pengguna kursi roda. Lain halnya dengan yang terjadi di Kabul, Afganistan, Hasanzada (2002) menyebutkan bahwa akses menuju gedung-gedung publik mendapatkan lebih sedikit perhatian, sehingga menyebabkan "perampasan" sejumlah hak-hak penyandang disabilitas dalam menikmati hak nya sebagai warga negara. Aksesibilitas menuju tempattempat umum merupakan masalah serius yang dihadapi penyandang disabilitas di negara ini. Selanjutnya Akinpelu \& Sadri, (2017) menyebutkan bahwa aksesibilitas bagi penyandang disabilitas pada ruangruang publik di Lagos State, Nigeria merupakan hal yang paling diabaikan dalam konstruksi ruang-ruang tersebut. Sehingga kelompok penyandang disabilitas mengalami kesulitan dalam hal mengakses dan menggunakan ruang-ruang publik tersebut. Hal senada juga diungkapkan oleh Evcil (2009) dalam penelitiannya yang menunjukkan bahwa pengguna kursi roda masih banyak mengalami masalah aksesibilitas dalam menggunakan fasilitas publik di Kota Istanbul, Turki.

Untuk memberikan kenyamanan bagi masyarakat berkebutuhan khusus, dalam Permenpan No. 17 Tahun 2017 disebutkan bahwa sarana dan prasarana bagi yang masyarakat berkebutuhan khusus yang perlu tersedia meliputi, parkir khusus, step lobby/ ramp bagi pengguna kursi roda, toilet khusus difabel, loket khusus, petugas khusus, kursi roda, ruang laktasi/ nursery, arena bermain anak, dan lain-lain. Mengacu ketentuan ini, maka delapan sarana-prasarana khusus tersebut adalah standar minimal yang perlu ada dan masih diperlukan standar optimal sarana-prasarana masyarakat berkebutuhan khusus yang lebih lengkap dan ideal.

Atas dasar hal tersebut serta melihat pada kondisi pemenuhan sarana dan prasarana bagi masyarakat berkebutuhan khusus pada sektor publik di lingkungan pemerintah daerah, penulis merasa perlu untuk mengulas lebih mendalam mengenai standar ideal sarana-prasarana bagi masyarakat berkebutuhan khusus serta bagaimana kesiapan unit penyedia pelayanan publik pada lingkup pemerintah daerah dalam menyediakan sarana-prasarana khusus kepada masyarakat berkebutuhan khusus tersebut. Dengan demikian, diharapkan pelayanan prima dapat tercipta serta tidak terdapat kesenjangan dalam memberikan pelayanan terbaik kepada seluruh lapisan pengguna layanan.

Hal ini penting dilakukan agar ketersediaan sarana dan prasarana tidak menghalangi kelompok berkebutuhan khusus untuk mengakses fasilitas publik serta untuk menjamin bahwa pelayanan publik juga dapat dirasakan dan diakses secara adil oleh masyarakat berkebutuhan khusus. Selain itu, sudah menjadi tanggung jawab pemerintah untuk mewujudkan pelayanan publik yang ramah terhadap masyarakat berkebutuhan khusus, serta sebagai upaya mewujudkan Sustainable Development Goals (SDGs) dengan arah tata kelola pemerintahan yang inklusif, dengan secara spesifik menyasar pada kelompok berkebutuhan khusus (no one left behind) (Susanto \& Sudiro, 2018; Bappenas, 2020)

\section{METODE}

Penelitian ini merupakan penelitian kualitatif deskriptif dengan terlebih dahulu melakukan analisis terhadap literatur yang ada (library research). Selanjutnya pengumpulan data melalui pengamatan lapangan (observasi), wawancara, dan sumber pustaka lainnya. Jenis observasi yang diterapkan yakni observasi terbatas (dilakukan dalam waktu tertentu dan peneliti tidak terlibat didalamnya) dan observasi sistemik yakni peneliti menggunakan pedoman (dua puluh dua sarana dan prasarana yang direkomendasikan) sebagai instrumen pengamatan yang ditetapkan sebagai standar untuk mengetahui kelengkapan sarana-prasarana pelayanan publik bagi masyarakat berkebutuhan khusus.

Penelitian ini dilakukan di tiga lokus berbeda selama enam bulan yakni di Kota X, Kabupaten Y, serta Kabupaten Z. Pemilihan ketiga lokus ini merujuk pada daerah-daerah yang menjadi lokus evaluasi pelayanan publik oleh Kemenpan-RB. Adapun unit pelayanan publik yang diobservasi pada daerah sampel adalah Dinas Kependudukan dan Pencatatan Sipil (Disdukcapil), Rumah Sakit Umum Daerah (RSUD), 
serta Dinas Penanaman Modal dan Pelayanan Terpadu Satu Pintu (DPMPTSP).

Pemilihan PTSP sebagai unit yang dievaluasi, karena PTSP merupakan unit terdepan dalam pemberian pelayanan perizinan, sehingga pelayanan yang diberikan akan berpengaruh pada kemudahan berinvestasi di wilayah tersebut. RSUD dipilih karena merupakan layanan dasar utama bagi masyarakat, sedangkan Disdukcapil dipilih sebagai unit yang dinilai karena layanan kependudukan merupakan layanan dasar yang akan berpengaruh pada pelaksanaan program pemerintah lainnya (Deputi Bidang Pelayanan Publik-KemenpanRB, 2019).

\section{HASIL DAN PEMBAHASAN}

Pelayanan publik tidak lepas dari administrasi publik yang diterapkan banyak negara. Seperti yang disampaikan Janet Denhardt \& Robert Denhardt dalam Puspitosari, Khalikussabir, Kurniawan, \& Lutfi (2011), pelayanan publik merupakan salah satu isu atau tujuan penting dari administrasi publik yang meliputi penyelenggaraan pemberian jasa-jasa publik, urusanurusan publik (kepentingan dan kebutuhan publik) serta pemberian pelayanan publik yang adil dan tidak diskriminatif. Dalam perspektif teori New Public Service (NPS), pelayanan publik dikembangkan berdasarkan upaya untuk memenuhi dan mengakomodasi nilai-nilai kebutuhan dan kepentingan publik yang didefinisikan melalui proses dialog publik yang rasional dengan pertimbangan politik, ekonomi maupun organisasional. Dengan demikian peran pemerintah tidak lagi steering atau rowing sebagaimana yang digambarkan dalam teori Old Public Administration (OPA) dan New Public Management (NPM), namun lebih kepada serving, dan posisi publik bukan lagi sekedar klien, kostituen ataupun pelanggan, tetapi lebih sebagai warga negara (citizen).

Pelayanan publik memiliki peran yang strategis dalam pengembangan good governance. Kegiatan pelayanan publik merupakan produk pemerintah dalam menjalankan fungi pelayanan, selain fungsi birokrasi pemerintahan yang lain. Perbaikan yang dilakukan pemerintah di sektor pelayanan publik tentunya menggambarkan perbaikan pelaksanaan fungsi pelayanan oleh pemerintah yang juga mengindikasikan penerapan good governance (PKP2A III LAN, 2013). Maka peningkatan kualitas pelayanan publik menjadi keharusan untuk terus menerus dilakukan oleh penyelenggara pelayanan publik di Indonesia.

Salah satu upaya meningkatkan kualitas pelayanan publik tersebut adalah dengan memperhatikan asas-asas keadilan dan nondiskriminatif terhadap masyarakat berkebutuhan khusus. Salah satu model yang dipakai dalam kebijakan penanganan masyarakat berkebutuhan khusus adalah model sosial. Model Sosial umumnya beranjak dari pemikiran bahwa hambatan-hambatan yang berasal dari luar lingkungan, yang menyebabkan ketidakmampuan seseorang yang mengalami impairment dalam melakukan aktivitas sehari-hari, terjadi karena lingkungan tidak mengakomodasi kebutuhan warga negara penyandang cacat/ kebutuhan khusus. Misalnya, arsitektur bangunan didisain dalam bentuk berundakundak sehingga pengguna kursi roda tidak dapat masuk atau menggunakan bangunan tersebut. Oleh sebab itu hak-hak masyarakat berkebutuhan khusus haruslah dilindungi. Melalui perlindungan hukum hak-hak warga negara berkebutuhan khusus, akan dapat terlaksana persamaan kesempatan dan partisipasi penuh penyandang cacat dalam berbagai aspek hidup dan kehidupan (Pramudiana, 2016).

Fasilitas dan perlakuan khusus bagi masyarakat berkebutuhan khusus yang tercantum dalam UndangUndang Nomor 25 Tahun 2009 adalah suatu upaya dari pemerintah dalam mewujudkan keadilan dalam suatu pelayanan publik. Warga negara yang termasuk dalam masyarakat berkebutuhan khusus sesuai dengan UU No. 25 Tahun 2009 adalah penyandang disabilitas (cacat), lanjut usia, wanita hamil, anak-anak, korban bencana alam, dan korban bencana sosial. Perlakuan khusus baik berupa peralatan dan fasilitas untuk kelompok tersebut diberikan tanpa adanya biaya tambahan. Lebih lanjut dalam Undang-Undang Nomor 8 Tahun 2016 tentang Penyandang Disabilitas juga menyatakan bahwa Pemerintah dan Pemerintah daerah wajib menyediakan pelayanan publik yang mudah diakses sesuai dengan peraturan perundang-undangan. Masyarakat berkebutuhan khusus merupakan bagian dari masyarakat yang membutuhkan perhatian khusus dalam upaya memperbaiki kehidupannya di lingkungan bermasyarakat (Humaedi, Wibowo, \& Raharjo, 2020).

Layanan publik yang aksesibel bagi seluruh warga negara tanpa membedakan asal-usul maupun bentuk fisik seseorang adalah suatu kebutuhan yang harus dipenuhi oleh pemerintah. Aksesibilitas memberikan kesempatan yang sama terhadap masyarakat berkebutuhan khusus untuk dapat mengaktualisasikan diri secara mandiri sehingga dapat berpartisipasi, berkontribusi dan berinteraksi dalam kegiatan bermasyarakat. Dengan aksesibilitas yang terpenuhi maka akan memudahkan bagi masyarakat berkebutuhan khusus dalam melakukan mobilitas dan mendapatkan pelayanan publik. Karena pelayanan publik adalah hak bagi setiap warga negara. Secara umum, aksesibilitas menurut Evcil (2009) adalah kebebasan atau kemampuan penyandang disabilitas/masyarakat berkebutuhan khusus (pengguna kursi roda, ibu dengan bayi, manula dan anak-anak) untuk mencapai kebutuhan dasar mereka sehingga dapat meningkatkan kualitas hidup mereka. Selanjutnya, Menurut Undang-Undang No. 8 Tahun 2016 tentang Penyandang Disabilitas, Aksesibilitas adalah kemudahan-kemudahan yang disediakan untuk Penyandang Disabilitas dalam mewujudkan Kesamaan Kesempatan. Sedangkan menurut Henry, Abou-Zahra, \& Brewer (2014) menekankan bahwa aksesibilitas 
lebih mengacu pada desain layanan bagi orang-orang penyandang disabilitas.

Untuk mewujudkan pelayanan publik yang ramah bagi masyarakat berkebutuhan khusus, maka dibutuhkan sarana dan prasarana penunjang di tiap-tiap gedung pelayanan publik hingga moda transportasi dan jalan umum. Penyediaan sarana dan prasarana bagi kelompok berkebutuhan khusus merupakan suatu bentuk dukungan moril bagi penyandang disabilitas. Pemenuhan terhadap berbagai sarana dan prasarana penunjang pelayanan publik merupakan suatu bentuk penghormatan dalam mendukung kaum rentan dalam proses mendapatkan pelayanan publik (Buana \& Rudy, 2018). Apabila merujuk pada Permenpan-RB Nomor 17 Tahun 2017 tentang Pedoman Penilaian Kinerja Unit Penyelenggara Pelayanan Publik, maka terdapat beberapa fasilitas yang dirasa sangat perlu bagi penyandang disabilitas dan masyarakat berkebutuhan khusus. Fasilitas tersebut antara lain ramp, kursi roda, parkiran khusus, toilet khusus, tempat duduk khusus, lift, dan loket khusus penyandang disabilitas dan masyarakat berkebutuhan khusus. Walaupun demikian, aturan ini masih jauh dari implementasinya. Masih banyak ditemukan minimnya fasilitas khusus penyandang disabilitas dan masyarakat berkebutuhan khusus di kantor-kantor pemerintahan. Padahal dalam pelaksanaannya, aksesibilitas fisik ke suatu kantor dan tempat-tempat umum merupakan suatu alasan untuk meningkatkan partisipasi penyandang disabilitas/masyarakat berkebutuhan khusus dalam mendapatkan hak-hak mereka (Hasanzada, 2002).

Untuk mendorong pelayanan yang lebih baik bagi masyarakat berkebutuhan khusus, maka penyediaan fasilitas atau sarana-prasarana yang mendukung menjadi sebuah hal mutlak. Dari berbagai literatur yang ada dapat dianalisis kebutuhan sarana dan prasarana bagi masyarakat berkebutuhan khusus sebagai berikut:

Tabel 1. Identifikasi Sarana Prasarana Publik Bagi Masyarakat Berkebutuhan Khusus

\begin{tabular}{lll}
\hline & $\begin{array}{c}\text { Sarana dan Prasarana Khusus } \\
\text { Masyarakat berkebutuhan khusus }\end{array}$ & \multicolumn{1}{c}{ Source } \\
\hline - & $\begin{array}{l}\text { Pegangan Rambatan (Handrail) } \\
\text { - } \begin{array}{l}\text { Jalur khusus bagi tunanetra } \\
\text { (tactile markings) }\end{array}\end{array}$ & $\begin{array}{l}\text { Atuahene, \& } \\
\text { Agyekum, } \\
\text { 2019) }\end{array}$ \\
\hline - & Jalur Landai (ramp) & (Salzman, \\
- & Pintu yang lebih luas/ & Matter, \& \\
& menggunakan engsel offset agar \\
pintu dapat terbuka lebih lebar & Ganapathiraju, \\
& 2015) \\
agar memudahkan pengguna & \\
kursi roda & \\
Jalur alternatif khusus disabilitas & \\
- Pegangan tambahan di toilet/ & \\
toilet disabilitas & \\
- Parkiran khusus disabilitas & \\
- & Lift & \\
Penambahan huruf braile/braille & \\
\hline
\end{tabular}

\begin{tabular}{|c|c|c|}
\hline & indikator di tombol lift & \\
\hline $\begin{array}{l}- \\
- \\
-\end{array}$ & $\begin{array}{l}\text { Guiding block/ penunjuk jalan/ } \\
\text { paving block tunanetra } \\
\text { Jalur landai/ ramp } \\
\text { Toilet khusus disabilitas } \\
\text { Parkir khusus disabilitas }\end{array}$ & $\begin{array}{l}\text { (Thohari, } \\
\text { 2014) }\end{array}$ \\
\hline $\begin{array}{l}- \\
- \\
- \\
-\end{array}$ & $\begin{array}{l}\text { Ramp/ jalur landai } \\
\text { Lift } \\
\text { Pintu otomatis } \\
\text { Toilet khusus disabilitas } \\
\text { Parkir khusus disabilitas }\end{array}$ & $\begin{array}{l}\text { Andayani, } \\
\text { ro'fah dan } \\
\text { muhrisun } \\
\text { dalam } \\
\text { (Syafi'ie, } \\
2014 \text { ) } \\
\end{array}$ \\
\hline & $\begin{array}{l}\text { Penunjuk jalan bagi disabilitas } \\
\text { Staf yang telah diajarkan untuk } \\
\text { memandu orang dengan } \\
\text { berkebutuhan khusus dan } \\
\text { menguasai dasar-dasar bahasa } \\
\text { isyarat } \\
\text { Kursi roda } \\
\text { Jalur kursi roda yang } \\
\text { sesuai/ramp } \\
\text { Menyediakan alarm darurat di } \\
\text { toilet khusus disabilitas } \\
\text { Tempat duduk khusus disabilitas } \\
\text { yang lebih dekat ke meja layanan }\end{array}$ & $\begin{array}{l}\text { (Kadir \& } \\
\text { Jamaludin, } \\
\text { 2013) }\end{array}$ \\
\hline- & $\begin{array}{l}\text { Pegangan untuk menaiki } \\
\text { tangga/railing steps } \\
\text { Jalur landai/ Ramp } \\
\text { Kursi roda } \\
\text { Alat bantu berdiri/crutches stand } \\
\text { Penunjuk jalan dari tempat parkir } \\
\text { disabilitas ke pintu masuk } \\
\text { Ketersediaan parkir untuk } \\
\text { disabilitas } \\
\text { Toilet khusus disabilitas } \\
\text { Ketersediaan pegangan } \\
\text { rambatan/Handrails } \\
\text { Tangga dengan warna yang } \\
\text { kontras }\end{array}$ & $\begin{array}{l}\text { (Venkatesan, } \\
\text { Jayakaran, } \\
\text { Purusotham, } \\
\text { \& Rafi, 2012) }\end{array}$ \\
\hline- & $\begin{array}{l}\text { Tempat parkir khusus disabilitas } \\
\text { yang dapat diakses } \\
\text { Toilet khusus disabilitas } \\
\text { Jalur landai/Ramp } \\
\text { Alarm yang dapat dijangkau } \\
\text { pengguna kursi roda } \\
\text { Tempat duduk untuk pengguna } \\
\text { kursi roda/tempat duduk khusus } \\
\text { Lift }\end{array}$ & $\begin{array}{l}\text { (U.S General } \\
\text { Services, } \\
2015)\end{array}$ \\
\hline & $\begin{array}{l}\text { Children playground; } \\
\text { Ruang laktasi; } \\
\text { Loket khusus masyarakat } \\
\text { berkebutuhan khusus }\end{array}$ & $\begin{array}{l}\text { Permenpan- } \\
\text { RB No. 17/ } \\
2017\end{array}$ \\
\hline
\end{tabular}

Dari hasil penelusuran literatur dan kebijakan yang ada sesuai Tabel 1, dapat diidentifikasi dan ditetapkan dua puluh dua sarana dan prasarana yang diperlukan untuk dapat optimal memberikan pelayanan kepada masyarakat berkebutuhan khusus. Dua puluh 
dua standar sarana dan prasarana tersebut akan menjadi dasar pijakan bagi penelitian ini untuk menilai kelengkapan yang tersedia bagi masyarakat berkebutuhan khusus di masing-masing daerah sampel penelitian. Adapun dua puluh dua sarana dan prasarana yang direkomendasikan bagi pelayanan masyarakat berkebutuhan khusus tersebut yaitu, (1) Pegangan rambatan (handrail); (2) Jalur khusus bagi tunanetra (tactile markings)/ guiding block; (3) Jalur Landai (ramp); (4) Pintu yang lebih luas/ pintu dapat terbuka lebih lebar agar memudahkan pengguna kursi roda/ Pintu Otomatis; (5) Jalur alternatif khusus disabilitas (menghubungkan semua ruang); (6) Parkiran khusus disabilitas; (7) Lift dengan huruf braile/braille indicator; (8) Penunjuk jalan/ ruangan/ layanan yang terlihat jelas; (9) Toilet khusus disabilitas; (10) Pegangan tambahan di toilet disabilitas; (11) Menyediakan alarm darurat di toilet khusus disabilitas; (12) Staf yang telah diajarkan untuk memandu orang dengan berkebutuhan khusus; (13) Staf yang menguasai dasar-dasar bahasa isyarat; (14) Kursi roda/ tongkat/ krek (crutches stand); (15) Tempat duduk khusus/ ruang tunggu khusus disabilitas yang lebih dekat ke meja layanan; (16) Pegangan untuk menaiki tangga/ railing steps; (17) Tangga dengan warna yang kontras; (18) Alarm yang dapat dijangkau pengguna kursi roda; (19) Children playground; (20) Ruang laktasi; (21) Loket khusus masyarakat berkebutuhan khusus; (22) Alat Bantu Tunarungu (hearing aid).

Secara umum dua puluh dua standar sarana prasarana yang direkomendasikan perlu tersedia bagi pelayanan masyarakat berkebutuhan khusus tersebut, relatif belum dapat dipenuhi seluruhnya di 3 lokus penelitian. hal ini kemungkinan disebabkan karena terbatasnya pengetahuan unit pelayanan publik terkait sarana dan prasarana apa saja yang masih perlu disediakan bagi masyarakat berkebutuhan khusus. Oleh karenanya, dengan adanya dua puluh dua standar sarana dan prasarana yang direkomendasikan oleh penelitian ini, unit penyedia layanan publik memiliki dasar untuk memenuhi kekurangan tersebut.

\section{Kota X}

Kota X merupakan kota metropolitan dengan jumlah penduduk mencapai 2.226 .812 jiwa. Secara umum pelayanan publik bagi masyarakat berkebutuhan khusus telah mampu dipenuhi dengan baik. Fasilitas yang disediakan relatif lengkap dan berfungsi dengan baik. Untuk penyelenggaraan pelayanan publik di RSUD Kota X serta PTSP Kota X, gambaran kelengkapan fasilitas masyarakat berkebutuhan khusus yang tersedia dapat dilihat seperti dokumentasi pada Gambar 2. Beberapa diantaranya seperti tersedia parkir khusus dan petugas keamanan serta CCTV; tempat duduk prioritas; toilet khusus; ruang laktasi; ruang bermain anak; kursi roda; petugas khusus pemandu layanan; loket khusus; handrail; guiding block, serta stamp ramp. Namun, khusus pada instansi Disdukcapil Kota $\mathrm{X}$ ditemukan belum tersedianya kursi prioritas bagi masyarakat berkebutuhan khusus serta petugas khusus pemandu layanan.

Gambar 2. Beberapa Fasilitas Bagi Masyarakat berkebutuhan khusus di Kota X

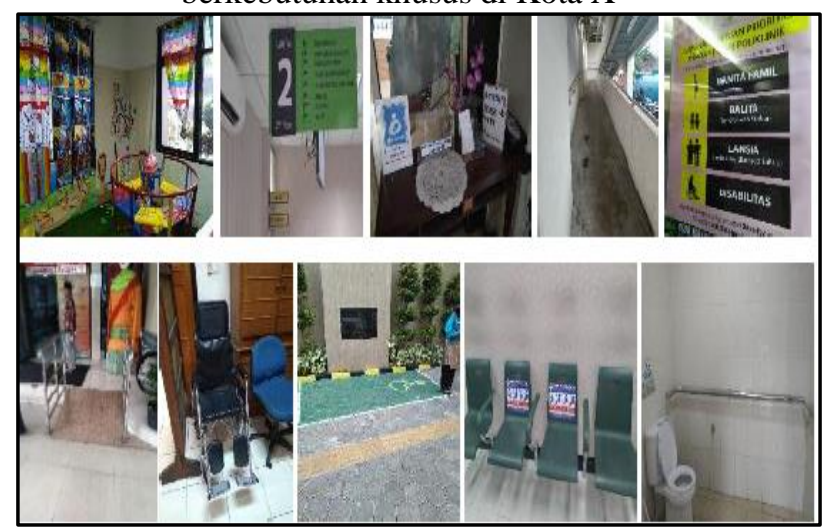

Sumber: Dokumentasi Penulis

Dalam interview yang dilakukan dengan para pimpinan penyedia pelayanan publik tersebut, secara umum memiliki concern yang cukup tinggi terhadap peningkatan kualitas pelayanannya. Termasuk senantiasa berupaya memenuhi kelengkapan pelayanan bagi masyarakat berkebutuhan khusus sebaik dan selengkap mungkin. Untuk mengoptimalkan pelayanan bagi masyarakat berkebutuhan khusus beberapa fasilitas lainnya masih perlu dilengkapi seperti penyediaan fasilitas tongkat dan krek; penyediaan alarm darurat di toilet khusus disabilitas; Staf yang menguasai dasar-dasar bahasa isyarat; Tangga dengan warna yang kontras; Alarm yang dapat dijangkau pengguna kursi roda; serta Alat bantu tunarungu.

\section{Kabupaten Y}

Kabupaten Y merupakan salah satu kabupaten di Provinsi Jawa Timur yang memiliki jumlah penduduk 1.189.106 jiwa dengan besaran APBD yang mencapai Rp 2,9T pada tahun 2019. Pada unit pelayanan publik di Kabupaten Y, rata-rata sudah memiliki sarana dan prasarana yang menunjang kebutuhan pelayanan bagi masyarakat berkebutuhan khusus. Saat ini telah tersedia parkir khusus difabel yang telah ditempatkan di dekat ruang pelayanan dan cukup mudah diakses. Khusus di Disdukcapil Kabupaten Y, tanda khusus penyandang disabilitas pada area parkir perlu diperjelas untuk menghindari pengguna lainnya menggunakan fasilitas tersebut. Jalur landai, rambatan, dan kursi roda juga tersedia, namun pada DPMPTSP Kabupaten Y penempatannya perlu di depan unit layanan agar terlihat jelas dan dapat dengan mudah untuk langsung digunakan.

Fasilitas tempat bermain anak serta bagi ibu menyusui juga telah disediakan ruang khusus laktasi dilengkapi fasilitas untuk mengganti popok bayi. Selain itu, tersedia fasilitas tempat duduk prioritas bagi difabel, ibu hamil, dan lansia. Namun pada instansi DPMPTSP kursi prioritas ini perlu secara spesifik 
dijelaskan kedudukannya karena masih tertera kursi disabilitas saja. Adapun toilet khusus penyandang disabilitas juga tersedia (dengan pilihan kloset duduk) meskipun masih bersatu dengan toilet wanita seperti terlihat di instansi Disdukcapil dan DPMPTSP, namun pada RSUD Kabupaten $\mathrm{Y}$ sudah terpisah dan dilengkapi fasilitas pegangan besi. Namun pada instansi DPMPTSP perlu dilengkapi fasilitas pegangan besi.

Untuk pelayanan sendiri, tersedia loket khusus dan petugas khusus yang memprioritaskan masyarakat berkebutuhan khusus untuk diutamakan mendapatkan pelayanan. Tersedia pula duta pelayanan yang menyambut setiap pengunjung yang datang dan memberikan informasi terkait jenis pelayanan yang hendak dituju oleh pengunjung. Adapun petugas yang khusus untuk membantu masyarakat berkebutuhan khusus serta menguasai pengetahuan khusus kelompok disable belum tersedia.

Gambar 3. Beberapa Fasilitas Bagi Masyarakat berkebutuhan khusus di Kabupaten Y

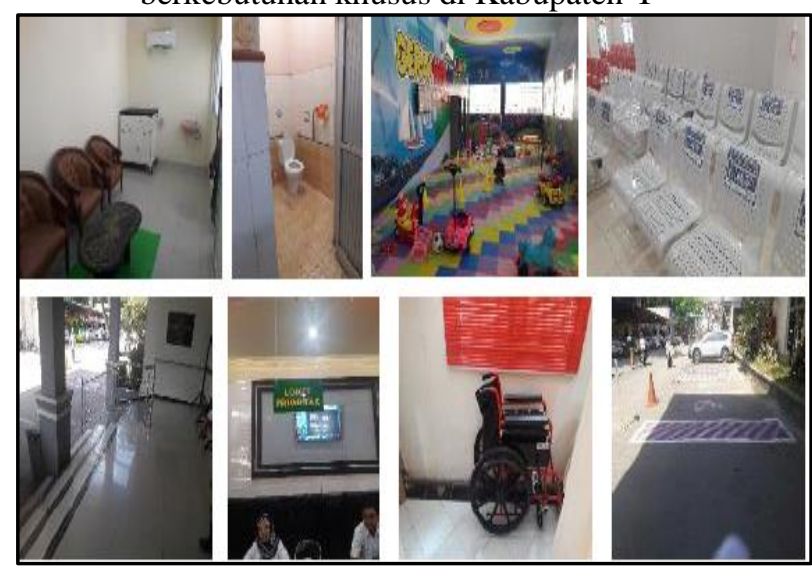

Sumber: Dokumentasi Penulis

Hasil wawancara dengan pimpinan unit pelayanan publik menunjukkan bahwa penyelenggara layanan publik sangat bersemangat untuk memenuhi kelengkapan penunjang pelayanan publik. Mereka menginginkan agar ada sosialisasi terkait sarana dan prasarana yang dibutuhkan bagi masyarakat berkebutuhan khusus sehingga dapat dipenuhi agar dapat memberikan pelayanan terbaik kepada seluruh lapisan pengguna layanan. Kelengkapan sarana dan prasarana yang dimiliki pada tiga unit pelayanan publik tersebut akan mendorong kepuasan masyarakat serta diharapkan dapat ditiru oleh unit pelayanan publik lainnya, sehingga pelayanan publik yang disediakan oleh Pemerintah Kabupaten Y memiliki standar yang sama.

Hasil pengamatan di lapangan menilai beberapa kelengkapan lainnya yang perlu dilengkapi untuk dapat menunjang pelayanan bagi masyarakat berkebutuhan khusus. Beberapa kelengkapan lain yang belum tersedia adalah fasilitas tongkat dan krek; Jalur khusus bagi tunanetra (tactile markings)/ guiding block;
Menyediakan alarm darurat di toilet khusus disabilitas; Staf yang menguasai dasar-dasar bahasa isyarat; untuk unit layanan yang menggunakan tangga perlu dilengkapi dengan warna yang kontras; Alarm yang dapat dijangkau pengguna kursi roda; serta Alat bantu tunarungu (hearing aid).

\section{Kabupaten Z}

Kabupaten Z merupakan salah satu kabupaten di Provinsi Kalimantan Tengah dengan populasi penduduk sebanyak 111.527 jiwa (BPS, 2021) dengan besaran APBD tahun 2019 mencapai Rp 1,2 T. Dibandingkan dua daerah yang menjadi sampel penelitian, Kabupaten $\mathrm{Z}$ memiliki penduduk yang relatif sedikit, sehingga juga berimplikasi pada penyediaan sarana dan prasarana bagi masyarakat berkebutuhan khusus yang tidak selengkap dua daerah tersebut. Namun demikian, secara umum pemenuhan fasilitas bagi masyarakat berkebutuhan khusus juga tetap diupayakan oleh penyedia layanan pada fasilitasfasilitas utama. Hal ini dibuktikan dengan telah tersedianya children playground, ruang laktasi, kursi roda, kursi prioritas, serta jalur landai.

Gambar 4. Beberapa Fasilitas Bagi Masyarakat berkebutuhan khusus di Kabupaten $\mathrm{Z}$

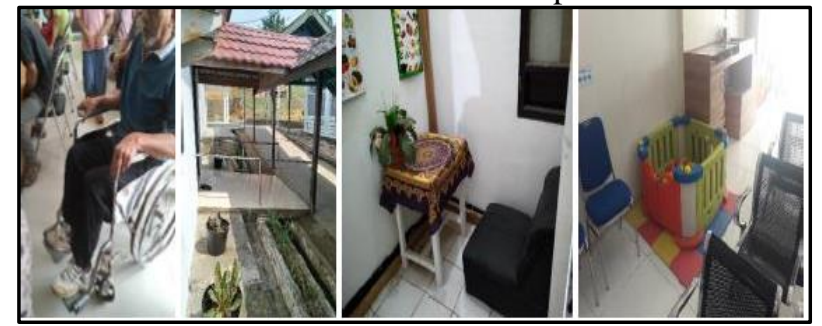

Sumber: Dokumentasi Penulis

Pada instansi DPMPTSP Kabupaten Z belum tersedia jalur randai (ramp), belum ada toilet khusus, belum ada kursi prioritas, serta belum ada ruang laktasi. Sedangkan pada RSUD Kabupaten Z belum ada parkir khusus, belum ada petunjuk arah yang jelas (kecil) bagi lansia, serta belum ada toilet khusus. adapun instansi Diskdukcapil Kabupaten Z hanya tersedia ruang laktasi namun untuk fasilitas lain belum tersedia seperti tidak ada petunjuk arah, tidak ada ramp, tidak ada toilet khusus, tidak ada kursi prioritas, tidak ada tempat bermain anak, tidak ada parkir khusus, serta tidak ada kursi roda.

Dari hasil wawancara yang dilakukan terhadap ketiga pimpinan instansi pelayanan publik tersebut secara umum menyebutkan bahwa keterbatasan anggaran menjadi hal utama yang menyebabkan beberapa fasilitas bagi masyarakat berkebutuhan khusus belum dipenuhi. Selain itu, jumlah masyarakat berkebutuhan khusus yang melakukan pengurusan layanan dirasakan tidak cukup banyak, sehingga fokus pembenahan kualitas pelayanan publik diprioritaskan pada kegiatan lainnya. Hal ini tentu dapat dipahami 
sebagai upaya pembenahan secara perlahan, namun ke depan pemenuhan fasilitas lainnya juga perlu dipertimbangkan oleh unit penyedia layanan publik.

Tercatat masih terdapat sekitar 12 fasilitas pendukung masyarakat berkebutuhan khusus yang perlu disediakan oleh Pemerintah Kabupaten Z melalui unit penyelenggara pelayanan publiknya agar memudahkan bagi masyarakat berkebutuhan khusus dalam melakukan pengurusan di unit pelayanan publik tersebut. Fasilitas-fasilitas tersebut meliputi handrail, guiding block, parkiran khusus disabilitas, toilet khusus disabilitas, pegangan tambahan di toilet disabilitas, menyediakan alarm darurat di toilet khusus disabilitas, staf yang telah diajarkan untuk memandu orang dengan berkebutuhan khusus, staf yang menguasai dasar-dasar bahasa isyarat, tangga dengan warna yang kontras, alarm yang dapat dijangkau pengguna kursi roda, loket khusus masyarakat berkebutuhan khusus, serta alat bantu tunarungu (hearing aid).

\section{Pembahasan}

Pemerintah sebagai penyedia layanan publik hingga saat ini belum memiliki pesaing, dengan kata lain masih bersifat monopolistik dalam penyediaan layanan publik. Meskipun pelanggan tidak bisa memilih bukan berarti pelayanan yang diberikan pemerintah tidak perlu dijaga kualitasnya. Kualitas pelayanan publik harus tetap dijaga, jika tidak maka salah satu kerugiannya adalah dapat menimbulkan rasa ketidakpedulian bahkan apatisme masyarakat terhadap penyedia layanan dan lembaga pemerintahan pada umumnya.

Oleh karena itu, menurut Simmons et al. (2009) dalam Irawan (2016) salah satu gerakan reformasi penting dalam sektor publik saat ini lebih menitikberatkan pada kebutuhan dan hak-hak individu, bukan sekedar dari hak-hak secara kolektif. Seperti halnya dalam pertimbangan seseorang yang berkebutuhan khusus yang tergabung dalam kelompok pengguna pelayanan publik, selain dapat berkontribusi dalam memahami hak-hak kolektif, juga dapat menjelaskan tentang hak-hak individu secara khusus dan tepat.

Pemenuhan terhadap fasilitas berupa sarana dan prasarana penunjang pelayanan bagi masyarakat berkebutuhan khusus merupakan langkah tepat untuk menunjukkan tata kelola pelayanan publik yang responsif, akuntabel, serta kualitas pada level tinggi. Dengan kata lain pola penyelenggaraan pelayanan publik seharusnya bersifat inklusif, di mana sistem pelayanan yang menjamin bahwa setiap orang memiliki kesempatan yang sama untuk dapat berpartisipasi dalam proses pelayanan, mengakui dan menghargai keragaman serta kebersamaan (Pramudiana, 2016).

\section{KESIMPULAN}

Menyediakan pelayanan dengan disertai fasilitas khusus bagi masyarakat berkebutuhan khusus merupakan kewajiban bagi penyedia layanan publik dan diberikan tanpa pembebanan biaya tambahan. Disamping itu, harapan akan peningkatan kepuasan masyarakat juga ditentukan oleh masyarakat berkebutuhan khusus.

Dari dua puluh dua standar yang direkomendasikan, 10 fasilitas khusus secara umum telah disediakan oleh penyedia layanan publik di tiga daerah yang menjadi sampel penelitian. Ditinjau per daerah, Kota X mampu memenuhi $77,27 \%$ atau 17 komponen, selanjutnya Kabupaten $\mathrm{Y}$ mampu memenuhi $72,27 \%$ atau 16 komponen sedangkan Kabupaten $\mathrm{Z}$ hanya mampu memenuhi 10 komponen atau $45,45 \%$. Dengan demikian, Kota X relatif lebih lengkap dalam memenuhi kebutuhan fasilitas pelayanan bagi masyarakat berkebutuhan khusus dibandingkan kedua daerah lainnya. khusus untuk Kabupaten $\mathrm{Z}$ masih diperlukan upaya yang cukup serius untuk melengkapi sarana dan prasarana bagi masyarakat berkebutuhan khusus di masa mendatang.

Namun demikian, keseluruhan daerah masih perlu memenuhi setidaknya lima sarana dan prasarana lainnya. Meliputi penyediaan alarm darurat di toilet khusus disabilitas, penyediaan pegawai yang menguasai dasar-dasar bahasa isyarat, penyediaan tangga dengan warna yang kontras, alarm yang dapat dijangkau pengguna kursi roda, serta alat bantu tunarungu (hearing aid). Selain itu, dari hasil pengamatan lapangan terlihat bahwa seluruh daerah hanya menyediakan fasilitas kursi roda bagi masyarakat berkebutuhan khusus, namun untuk fasilitas tongkat dan krek (crutches stand) relatif belum disediakan oleh seluruh penyedia layanan.

Perhatian penyelenggara pelayanan publik kepada masyarakat berkebutuhan khusus yang terdiri dari penyandang cacat, lanjut usia, wanita hamil, anakanak, korban bencana alam, dan korban bencana sosial menjadi sangat penting. Perhatian tersebut dapat diwujudkan melalui penyediaan layanan serta fasilitas khusus bagi mereka.

Untuk memenuhi standar pelayanan khusus tersebut, diperlukan political will pemimpin daerah untuk turut memprioritaskan penyediaan sarana dan prasarana penunjang pelayanan publik bagi masyarakat berkebutuhan khusus. Di tengah keterbatasan sumberdaya daerah, maka pengutamaan tahapan pemenuhan (road map) fasilitas khusus tersebut perlu disiapkan, serta pola-pola kemitraan dan kolaborasi dengan mitra strategis lainnya dapat dikembangkan untuk membantu memenuhi standar pelayanan khusus tersebut.

Setelah sarana dan prasarana khusus bagi masyarakat berkebutuhan khusus tersebut tersedia dan dapat dipenuhi oleh penyelenggara pelayanan publik pada ketiga daerah lokus penelitian tersebut, beberapa 
langkah lanjutan perlu dipersiapkan agar pemanfaatannya dapat optimal. Pertama, merancang standar operasional pelayanan (SOP) khusus bagi masyarakat berkebutuhan khusus agar pemanfaatan sarana dan prasarana khusus tersebut dapat lebih optimal. Pemberlakuan standar waktu tertentu, loket khusus, serta unsur petugas pelaksana khusus dalam SOP tersebut akan menjamin pelayanan yang paripurna bagi masyarakat berkebutuhan khusus. Penempatan petugas pemandu masyarakat berkebutuhan khusus di loket awal akan diperlukan untuk mengarahkan dan membantu masyarakat berkebutuhan khusus dalam memanfaatkan fasilitas khusus yang telah disediakan.

Langkah kedua adalah melakukan sosialisasi dan penyebarluasan informasi kepada stakeholders/ pengguna layanan terkait fasilitas khusus yang telah disediakan bagi masyarakat berkebutuhan khusus. penyebarluasan informasi ini penting dilakukan agar masyarakat berkebutuhan khusus mengetahui sarana dan prasarana khusus yang telah disiapkan sehingga tidak perlu khawatir dan merasa nyaman ketika melakukan pengurusan di unit pelayanan publik tersebut. Langkah ketiga, sebagai upaya pembenahan atas pelayanan yang diberikan, perlu dilakukan survey kepuasan masyarakat berkebutuhan khusus atas pelayanan yang telah diberikan. dalam survey tersebut dilakukan pengukuran tidak hanya terkait persyaratan, prosedur, kompetensi petugas, tetapi juga terkait kualitas sarana-prasarana yang telah disediakan. Langkah terakhir dan juga sangat penting adalah setiap unit pelayanan publik harus menjamin bahwa seluruh sarana dan prasarana dapat digunakan dan difungsikan secara layak oleh masyarakat berkebutuhan khusus. Keberadaan sarana dan prasarana yang berfungsi baik, nyaman digunakan, dan memadai jumlahnya akan menjadi ukuran penting dalam menunjang pelayanan prima bagi masyarakat berkebutuhan khusus.

\section{DAFTAR PUSTAKA}

Akinpelu, D. O., \& Sadri, S. Z. (2017). Accessibility of Public Spaces : Case Study of Ikeja, Lagos State , Nigeria. International Journal of Humanities and Social ScienceInvention(IJHSSI, 6(3), 1224. Retrieved from http://www.ijhssi.org/pape rs/v6(3)/version-II/C0603021224.pdf

Bappenas. (2020). Sekilas SDGs. Retrieved from http://sdgs.bappenas.go.id/sekilas-sdgs/

Buana, I. K. S., \& Rudy, D. G. (2018). Aksesibilitas Sebagai Bentuk Kemandirian Bagi Difabel Dalam Menggunakan Fasilitas Pelayanan Publik Pada Perbankan. Kertha Negara : Journal Ilmu Hukum, 7(1), 1-14. Retrieved from https://ojs.unud.ac.id/index.php/Kerthanegara/art icle/view/47249

Danso, A. ., Atuahene, B. ., \& Agyekum, K. (2019). Accessibility of Built Infrastructure Facilities for
Persons With Disabilities. Annals of the Faculty of Engineering Hunedoara - International Journal of Engineering, 17(4), 185-192. Retrieved from https://elib.tcd.ie/login?url=http://search.ebscoho st.com/login.aspx ?direct $=$ true $\& d b=a 9 h \& A N=14$ $1517193 \&$ site $=$ ehost-live

Deputi Bidang Pelayanan Publik-KemenpanRB (2019). LAKIP Deputi Bidang Pelayanan Publik. Retrieved from https://www.menpan.go.id/site/lakip

Evcil, A. N. (2009). Wheelchair accessibility to public buildings in Istanbul. Disability and Rehabilitation: Assistive Technology, 4(2), 7685. https://doi.org/10.1080/17483100802543247

Hasanzada, M. T. (2002). Physical Accessibility of Persons with Disabilities to Public Places. Afghanistan Independent Human Rights Commission, 1-28.

Henry, S. L., Abou-Zahra, S., \& Brewer, J. (2014). The role of accessibility in a universal web. W4A 2014 - 11th Web for All Conference. https://doi.org/10.1145/2596695.2596719

Humaedi, S., Wibowo, B., \& Raharjo, S. T. (2020). Potret Mantan Penderita Skizofrenia Ditinjau Dari Strength Perspective. Share : Social Work Journal, 10(1), https://doi.org/10.24198/share.v10i1.26896

Irawan, B. (2016). Kapasitas Organisasi dan Pelayanan Publik. Jakarta: Publica Press.

Kadir, S. A., \& Jamaludin, M. (2013). Staff Assistance as a Crucial Aspect of Accessibility in Public Buildings. Procedia - Social and Behavioral Sciences, 101, 140-146.

Keerthirathna, W. A. D., Karunasena, G., \& Rodrigo, V. A. K. (2018). Disability Access in Public Buildings. International Research Conference on Sustainability in Built Environment, (June 2010).

Kementerian PANRB. (2020). Kementerian PANRB Dorong Pemenuhan Sarpras Pelayanan Kaum Rentan. Retrieved from https://menpan.go.id/site/beritaterkini/kementerian -panrb-doro ng-pemenuhansarpras-pelayanan-kaum-rentan

Kementerian Perhubungan. (2021). Kemenhub Raih Penghargaan Sebagai Role Model Pelayanan Yang Ramah Kelompok Rentan Dari KemenPANRB. Retrieved from http://dephub.go.id/post/read/kemenhub-raihpenghargaan-sebagai-role-model-pelayananyang-ramah-kelompok-rentan-dari-kemenpanrb

Ndaumanu, F. (2020). Hak Penyandang Disabilitas . 
Antara Tanggung Jawab Dan Pelaksanaan Oleh Pemerintah Daerah (Disability Rights : Between Responsibility and Implementation By the Local Government). Jurnal HAM, 11(1), 131-150. https://doi.org/http://dx.doi.org/10.30641/ham.20 20.11.131-150

Ombudsman Republik Indonesia. (2018). Laporan Tahunan 2018. Retrieved from https://ombudsman.go.id/produk?c=19

Palenewen, J. D. O. (2019). Manajemen Pelayanan Publik: Tinjauan tentang Keadilan Akses Pelayanan Publik Bagi Kaum Difabel. JSPG: Journal of Social Politics and Governance, 1(1), 28-38.

Pasciana, R. (2020). Pelayanan Publik Inovatif Bagi Penyandang Disabilitas (Studi Kasus Di Kabupaten Garut). SAWALA Jurnal Administrasi Negara, 8(2), 192-204. https://doi.org/10.319 33/unesrev.v2i2.109

PKP2A III LAN. (2013). Inovasi Pelayanan Publik di Wilayah Kalimantan. Samarinda: PKP2A III Lembaga Administrasi Negara.

Pramudiana, I. D. (2016). Implementasi Kebijakan Pelayanan Publik Bagi Masyarakat Penyandang Cacat. 9(1), 25-30. Retrieved from https://journal.trunojoyo.ac.id/dimensi/article/vie w/3735

Propiona, J. K. (2021). Implementasi Aksesibilitas Fasilitas Publik Bagi Penyandang Disabilitas. Jurnal Analisa Sosiologi, 10(Edisi Khusus Sosiologi Perkotaan: Januari 2021), 1-18. https://doi.org/DOI:

https://doi.org/10.20961/jas.v10i0.47635

Puspitosari, H., Khalikussabir, Kurniawan, L. J., \& Lutfi, M. (2011). Filosofi Pelayanan Publik: Buramnya Wajah Pelayanan Menuju Perubahan Paradigma Pelayanan Publik. Malang: Setara Press dan Jaringan Nasional Masyarakat Peduli
Pelayanan Publik (MP3).

Salzman, C., Matter, R., \& Ganapathiraju, A. (2015). A Planning Guide for Making Temporary Events Accessible to People with Disabilities. ADA National Network, 61. Retrieved from https://adata.org/guide/planning-guide-makingtemporary-events-accessible-people-disabilities

Susanto, E., \& Sudiro, S. (2018). Studi Kajian Tingkat Aksesibilitas Pada Fasilitas Publik Bagi Penyandang Disabilitas (Berkebutuhan Khusus) di Kota Surakarta. Jurnal SAINSTECH Politeknik Indonusa Surakarta, 5(1), 19-32. Retrieved from http://sainstech.poltekindonusa.ac.id/index.php/v iew/article/view/10

Syafi'ie, M. (2014). Pemenuhan Aksesibilitas Bagi Penyandang Disabilitas. Inklusi, 1(2), 269. https://doi.org/https://doi.org/10.14421/ijds.0102 08

Thohari, S. (2014). Pandangan Disabilitas dan Aksesibilitas Fasilitas Publik bagi Penyandang Disabilitas di Kota Malang. Indonesian Journal of Disability Studies, 1(1), 27-37. Retrieved from

https://ijds.ub.ac.id/index.php/ijds/article/view/3 8

U.S General Services, A. (2015). National Accessibility Program. Retrieved from https://www.gsa.gov/real-estate/designconstruction/accessible-facility-design

Venkatesan, S., Jayakaran, G. T., Purusotham, P., \& Rafi, M. (2012). Disability access audit of public service facilities. Journal of All India Institute of Speech and Hearing, 31(January 2012), 190210. Retrieved from https://www.researchgate.net/publication/25835 9694_Disability_access_audit_of_public_service _facilities 